\title{
Kinetics of the Thermal Decomposition of Rhodochrosite
}

\author{
Iván A. Reyes ${ }^{1,2}{ }^{\mathbb{D}}$, Mizraim Flores ${ }^{3, *}$, Elia G. Palacios ${ }^{4} \mathbb{D}$, Hernán Islas ${ }^{1}$, Julio C. Juárez ${ }^{5} \mathbb{D}$, Martín Reyes $^{5}$, \\ Aislinn M. Teja ${ }^{5}$ (D) and Cristóbal A. Pérez ${ }^{1}$ (D)
}

1 Instituto de Metalurgia, Universidad Autónoma de San Luis Potosí, San Luis Potosí 78210, Mexico; alejandro.reyes@uaslp.mx (I.A.R.); islas_79hv@yahoo.com.mx (H.I.); cristobal.perez@uaslp.mx (C.A.P.)

2 Catedrático CONACYT, Consejo Nacional de Ciencia y Tecnología, Ciudad de Mexico 03940, Mexico

3 Área Electromecánica Industrial, Universidad Tecnológica de Tulancingo, Hidalgo 43642, Mexico

4 Escuela Superior de Ingeniería Química e Industrias Extractivas, Instituto Politécnico Nacional, Ciudad de Mexico 07738, Mexico; epalacios@ipn.mx

5 Área Académica de Ciencias de la Tierra y Materiales, Universidad Autónoma del Estado de Hidalgo, Hidalgo 42183, Mexico; jcjuarez@uaeh.edu.mx (J.C.J.); mreyes@uaeh.edu.mx (M.R.); ice9791@gmail.com (A.M.T.)

* Correspondence: mflores@utectulancingo.edu.mx

Citation: Reyes, I.A.; Flores, M.; Palacios, E.G.; Islas, H.; Juárez, J.C.; Reyes, M.; Teja, A.M.; Pérez, C.A. Kinetics of the Thermal Decomposition of Rhodochrosite. Minerals 2021, 11, 34 .

https://doi.org/10.3390/min11010034

Received: 18 November 2020 Accepted: 25 December 2020 Published: 29 December 2020

Publisher's Note: MDPI stays neutral with regard to jurisdictional clai$\mathrm{ms}$ in published maps and institutional affiliations.

Copyright: (C) 2020 by the authors. Licensee MDPI, Basel, Switzerland. This article is an open access article distributed under the terms and conditions of the Creative Commons Attribution (CC BY) license (https:// creativecommons.org/licenses/by/ $4.0 /)$.

\begin{abstract}
Manganese is a widely used element in the steel industry; its main source is a mineral named rhodochrosite $\left(\mathrm{MnCO}_{3}\right)$. For industrial usage, rhodochrosite is reduced to different manganese oxides by means of nodulation furnaces. In this study, rhodochrosite was thermally analyzed at temperatures ranging from $100{ }^{\circ} \mathrm{C}$ to $1200{ }^{\circ} \mathrm{C}$. XRD (Powder X-ray diffraction), XRF (X-ray fluorescence), AAS (Atomic Absorption Spectrometry), and FESEM-EDX (Field Emission Scanning Electron Microscopy-Energy Dispersive X-ray Spectrometry) were used to characterize the mineral and the residues were analyzed by XRD and FTIR (Fourier-transform infrared spectroscopy) to determine the stoichiometry of the thermal decomposition reactions. Three mass losses were observed, the first attributed to the transformation from carbonate to manganese (III) oxide, the second to the reduction to manganese tetroxide, and the third to the decomposition of calcium carbonate $\left(\mathrm{CaCO}_{3}\right)$ present as a contaminant in the studied mineral. Thermal decomposition kinetics shows that the first mass loss required $17.91 \mathrm{~kJ} \mathrm{~mol}^{-1}$, indicating a control by mass transport-controlled process. For the second and third mass loss, the apparent activation energy of $112.41 \mathrm{~kJ} \mathrm{~mol}^{-1}$ and $64.69 \mathrm{~kJ} \mathrm{~mol}^{-1}$ was obtained respectively, indicating that both mass loss events were rate-controlled.
\end{abstract}

Keywords: kinetics; apparent activation energy; thermal decomposition; manganese carbonate

\section{Introduction}

Manganese occurs in natural environments in the $2+, 3+$, and $4+$ oxidation states. The higher the oxidation states, the stronger the tendency of this element to hydrolyze and precipitate. The transport of $\mathrm{Mn}$ in aqueous solutions is generally favored by reducing conditions, and the $\mathrm{Mn}^{2+}$ ion and its complexes constitute the principal transport species [1]. Manganese is a relatively abundant element on the Earth's crust and most commonly occurs in a variety of oxides, oxyhydroxides, and carbonates such as pyrolusite $\left(\mathrm{MnO}_{2}\right)$, manganite $(\mathrm{MnO}[\mathrm{OH}])$, rhodochrosite $\left(\mathrm{MnCO}_{3}\right)$, and kutnahorite $\left.\left(\mathrm{CaMn} \mathrm{CO}_{3}\right]_{2}\right)$ [2]. Manganesebased materials, especially those formed by manganese oxides, are important for their relevant physical and chemical properties, which enable their use in important technological applications, such as rechargeable batteries, sensors, and optical or magneto-electronic devices. One of the main applications of manganese is in the steel industry, as manganese imparts malleability, tenacity, and hardness to steel. Moreover, the non-ferrous applications of manganese include the production of dry-cell batteries, plant fertilizer and animal food, and colorant for bricks [3-12]. Manganese-based solids with a spinel structure have also attracted attention as effective catalysts in the reduction of dangerous gases, such as $\mathrm{CO}$, $\mathrm{NO}$, and $\mathrm{N}_{2} \mathrm{O}$, and several organic compounds [3]. 
Depending on the Mn content, manganese ores are categorized into high grade (Mn 44\%), medium grade (Mn 40-44\%), low grade (Mn 35-40\%), and steel-mill grade (Mn 28-35\%) [13]. A giant stratiform rhodochrosite deposit is found in the town of Molango, in Hidalgo, Mexico, which is the major manganese deposit in North America. The ore horizon occurs in the Chipoco facies at the base of the Taman formation. The manganese extracted from this area is used to make ferroalloys. The rhodochrosite ore, though relatively low in manganese, is added to the blast furnace charge for the production of ferromanganese.

However, during the last five years, flotation and nodulizing processes have been developed, which concentrate the rhodochrosite ore into a high-grade product more suitable for manufacturing ferromanganese, reaching concentrations of $74 \%$ of Mn [14]. "Minera Autlán" in Molango owns the world's only nodulation rotary kiln for nodules production from manganese ore, which is used to improve the chemical and physical properties of manganese carbonates by converting them into manganese nodules. Following the concept of the cement clinker, the fine manganese ore is reacted in a refractory-lined counter-current rotary kiln with horizontal flow to produce nodules in which most of the manganese is in the divalent oxidation state. The process was first used in the USA and Norway for the treatment of manganese oxide ore fines. Since 1968, it has been used by Minera Autlan in Mexico for nodulizing carbonate ore fines. In the case of the Autlan ore, liquid formation required for nodulizing takes place at temperatures between $1145{ }^{\circ} \mathrm{C}$ and $1260{ }^{\circ} \mathrm{C}$ [15]. Nodulation is carried out to drive off volatiles (water and $\mathrm{CO}_{2}$ ), reducing the amount of excess oxygen (pre-reduction) and improving the size distribution (agglomeration or sintering) as well as the performance of the ore during melting in a submerged arc furnace. Previous studies have been conducted on the thermal decomposition of $\mathrm{MnCO}_{3}$. Kissinger et al. (1955) calculate the heat of reaction of each mass loss using thermodynamic data, determining that the first mass loss is an exothermic reaction, whereas the second and third mass losses are endothermic reactions [16]. Biernacki and Pokrzywnicki (1999) found that temperature accelerates the decomposition of $\mathrm{MnCO}_{3}$ to $\mathrm{MnO}_{2}$ which was faster at $691 \mathrm{~K}\left(418{ }^{\circ} \mathrm{C}\right)$ and calculated a value of $\Delta \mathrm{G}=-17 \mathrm{kcal} \mathrm{mol}^{-1}$; reduction reactions occur at $703-815 \mathrm{~K}\left(\mathrm{MnO}_{2}\right.$ to $\left.\mathrm{Mn}_{2} \mathrm{O}_{3}\right), 815-1300 \mathrm{~K}\left(\mathrm{Mn}_{2} \mathrm{O}_{3}\right.$ to $\left.\mathrm{Mn}_{3} \mathrm{O}_{4}\right)$ and above $1300 \mathrm{~K}\left(\mathrm{Mn}_{3} \mathrm{O}_{4}\right.$ to $\mathrm{MnO}$ ), where $\mathrm{MnO}$ is the most stable manganese oxide phase [17]. The Gibbs-free energy of and the enthalpy for the formation of rhodochrosite [18], have been also determined, however the kinetics of thermal decomposition of rhodochrosite have not been studied. Thermal decomposition of rhodochrosite is the main treatment process in the manganese industry; in this study, the kinetics of thermal decomposition of $\mathrm{MnCO}_{3}$ was investigated, and the apparent activation energies of the material mass losses during the process were obtained. The main contribution of this work is obtaining new kinetic parameters such as the apparent activation energy and the frequency factor for the thermal decomposition of rhodochrosite, which is a process of great importance in the production of manganese nodules by pyrometallurgy. Moreover, the stoichiometry of the decomposition reaction of manganese carbonate into different oxides is presented.

\section{Materials and Methods}

The rhodochrosite sample was obtained from the manganese ore deposit located in Molango, Hidalgo, Mexico. The sample was pulverized with an agate mortar to a size of 53 micrometers, homogenized, and analyzed using different characterization techniques such as Powder X-ray diffraction (XRD), X-ray fluorescence (XRF), Atomic Absorption Spectrometry (AAS), and Field Emission Scanning Electron Microscopy-Energy Dispersive X-ray Spectrometry (FESEM-EDX) a JEOL JSM-670 IF Field Emission Scanning Electron microscope was used (JEOL, Tokyo, Japan). The XRD analysis was performed using a Bruker D8 powder diffractometer (Bruker Corporation, Billerica, MA, USA), with Ni filtered radiation from a $\mathrm{Cu}$ anode $\left(\mathrm{k}_{\alpha 1}=1.5406 \AA ; 40 \mathrm{kV}\right.$ and $\left.35 \mathrm{~mA}\right)$. Diffraction patterns were recorded in the angular range $2 \theta$ of $10-90^{\circ}$, with a step size $=0.01^{\circ}$ and a step time $=3 \mathrm{~s}$. For the XRF analysis, an S2 PUMA equipment (Bruker) was utilized, using rhodochrosite 
powder less than $45 \mu \mathrm{m}$. For the AAS analysis, a PerkinElmer Analyst 200 (PerkinElmer Inc., Waltham, MA, USA), was utilized. The calibration of the equipment was carried out with certified standards, PerkinElmer of $1000 \mathrm{ppm}$ of the element to be determined.

For thermal characterization, thermogravimetric analysis was performed in a Mettler Toledo TG-DTG 851e equipment (Mettler Toledo, Greifensee, Switzerland). The experiments were carried out at a heating rate of $10^{\circ} \mathrm{C} \mathrm{min}-1$ and $666 \times 10^{-3} \mathrm{~m}^{3} \mathrm{~s}^{-1}$ air flow. Calcination was carried out for one hour at different temperatures $\left(450{ }^{\circ} \mathrm{C}, 750{ }^{\circ} \mathrm{C}\right.$ and $900{ }^{\circ} \mathrm{C}$ ), subsequently the calcined solids (powder) were analyzed by FESEM-EDX to determine the elemental composition at different temperatures. The calcination residues were later analyzed by XRD and Fourier-transform infrared spectroscopy (FT-IR) in a PerkinElmer Spectrum Two with Universal ATR (PerkinElmer Inc., Waltham, MA, USA) $3000-4500 \mathrm{~cm}^{-1}$ to infer the stoichiometry of the thermal decomposition reactions.

The kinetic analysis performed was based on an isothermal process using the "time to a given fraction" method [19-22]. The mass fractions for each temperature used in each mass loss ramp were determined. In the first stage, four temperatures were taken, due to the prolonged mass loss slope caused by the large amount of $\mathrm{CO}_{2}$ released; for the second and third stages, only three temperatures were considered, given that the slopes were short. Apparent activation energies accounting for the mass loss at each stage were obtained.

\section{Results and Discussion}

\subsection{Sample Characterization}

Figure 1 shows the XRD diffractogram of the sample used in this work, compared with the ICDD-PDF 96-900-7692, which belongs to rhodochrosite $\left(\mathrm{MnCO}_{3}\right)$. In this diffractogram, a compact hexagonal structure is observed, with crystal lattice parameters of a $=4.773 \AA$ and $c=15.642 \AA$, these parameters were calculated with Match! software (Version 3, Crystal Impact - Dr. H. Putz \& Dr. K.Brandenburg GbR, Kreuzherrenstr. 102, 53227 Bonn, Germany). The diffractogram only shows peaks characteristic of rhodochrosite.

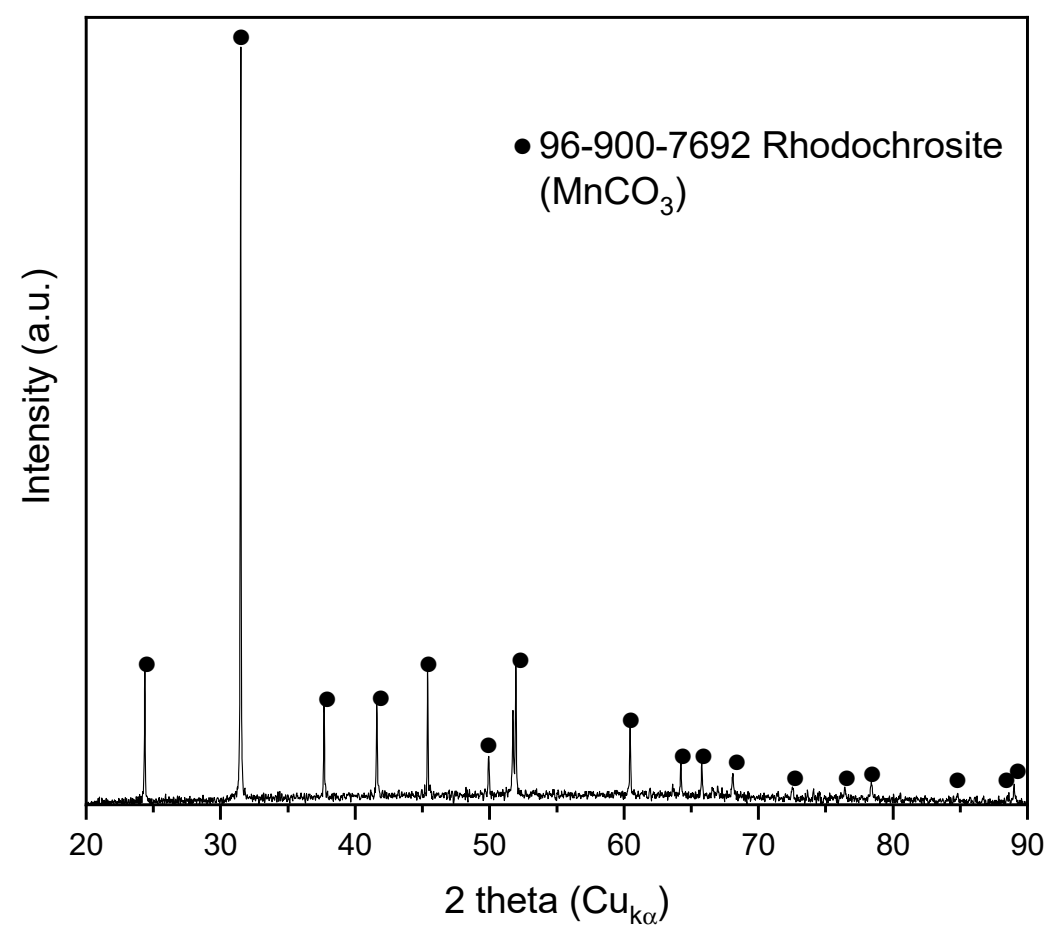

Figure 1. Rhodochrosite X-ray diffraction (XRD) diffractogram.

Table 1 shows the chemical analysis performed using XRF and small amounts of iron, magnesium, silicon, and calcium were found; these cations are present in additional carbonates species as impurities in the studied mineral. However, the high content of 
manganese confirms that the mineral sample is rhodochrosite. The manganese is frequently replaced by iron, magnesium and/or calcium as shown in this formula: $(\mathrm{Fe}, \mathrm{Mg}, \mathrm{Ca}) \mathrm{CO}_{3}$. These substitutions of other elements for manganese change the composition and alter the specific gravity, hardness, and color of the mineral. The bright pink color can become grayish, yellowish, or brownish in response to this chemical variability. A complete solid solution series exists between rhodochrosite and siderite $\left(\mathrm{FeCO}_{3}\right)$. Likewise, quantitative elemental chemical analysis was performed by AAS, showing results similar to those obtained by XRF, manganese being the element present in major proportion in the sample.

Table 1. Rhodochrosite chemical analyses by X-ray fluorescence (XRF) and Atomic Absorption Spectrometry (AAS).

\begin{tabular}{cccc}
\hline Element & wt. \% AAS & Compound & wt. \% XRF \\
\hline $\mathrm{Mg}$ & 5.21 & $\mathrm{MgCO}_{3}$ & 4.91 \\
$\mathrm{Si}$ & without detection & $\mathrm{SiO}_{2}$ & 2.95 \\
$\mathrm{Ca}$ & 1.03 & $\mathrm{CaCO}_{3}$ & 0.53 \\
$\mathrm{Mn}$ & 87.92 & $\mathrm{MnCO}_{3}$ & 86.89 \\
$\mathrm{Fe}$ & 5.79 & $\mathrm{FeCO}_{3}$ & 4.72 \\
\hline
\end{tabular}

Figure 2a shows a different particle sizes and Figure $2 \mathrm{~b}$ shows the analysis performed by EDX on the rhodochrosite sample. The characteristic peaks of $\mathrm{Mn}, \mathrm{Ca}, \mathrm{Si}, \mathrm{Mg}, \mathrm{Fe}$, and O are observed in the spectrum, which is consistent with the analysis performed by XRF. The calcium, iron and magnesium are present as carbonates species, while silicon is found as oxide.
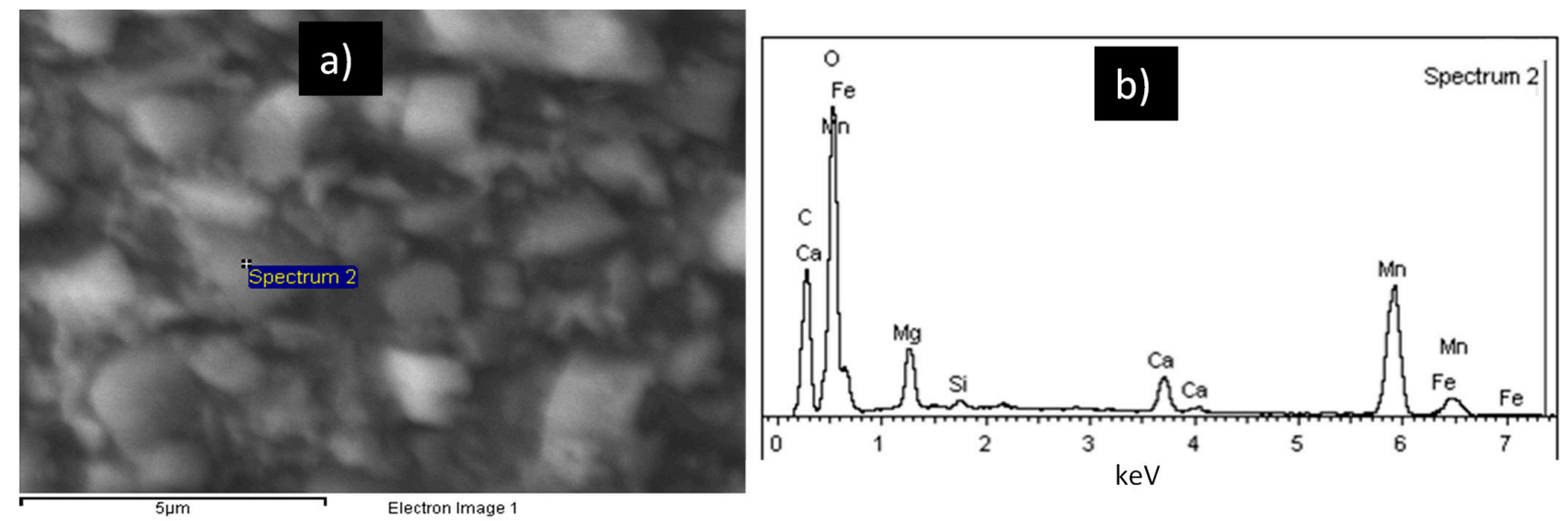

Figure 2. Imagen of rhodochrosite by Field Emission Scanning Electron Microscopy (FESEM) (a) and Energy Dispersive X-ray Spectrometry (EDX) spectrum (b).

Figure 3 shows the results of the thermogravimetric and differential thermal analysis (TG-DTG) of the rhodochrosite sample, which was carried out at temperatures ranging from $100{ }^{\circ} \mathrm{C}$ to $1200^{\circ} \mathrm{C}$. The sample undergoes three mass losses during the thermal analysis. The first mass loss is $27.5 \%$, which starts at $350^{\circ} \mathrm{C}$ and ends at approximately $660^{\circ} \mathrm{C}$. It is attributed to the transformation of manganese carbonate $\left(\mathrm{MnCO}_{3}\right)$ into manganese III oxide $\left(\mathrm{Mn}_{2} \mathrm{O}_{3}\right)$; this is confirmed by the XRD analysis (Figure 4), which matches the oxide reference data ICDD-PDF 96-900-752. In this first mass loss, the carbonate dissociation results in the emission of $\mathrm{CO}_{2}$. The second mass loss starts at approximately $660^{\circ} \mathrm{C}$ and ends at $800^{\circ} \mathrm{C}$ and is attributed to the conversion of manganese (III) oxide to manganese (II, III) oxide; this is confirmed again by XRD, where $\mathrm{Mn}_{3} \mathrm{O}_{4}$ was identified according to the ICDD-PDF 96-900-1964 pattern (Figure 4) [23,24]. Finally, the third mass loss of 1.4\% which begins at $800{ }^{\circ} \mathrm{C}$ and ends at $910^{\circ} \mathrm{C}$, is attributed to the decomposition of calcium carbonate; this can be verified by FESEM-EDX analysis, made to calcined powders at $900{ }^{\circ} \mathrm{C}$ which shows all the elements detected in the initial sample (Figure 5), except for 
calcium and carbon. Calcium carbonate is transformed into oxide, however, the small amount of calcium in the residues was not detected by the EDX. The decomposition of iron and magnesium carbonates occurs at 350 and $600{ }^{\circ} \mathrm{C}$ respectively, remaining as oxides in the sample. The conversion of carbonate to manganese oxide occurs quickly and has been reported to be due to an endothermic reaction [16]. The product is $\alpha-\mathrm{Mn}_{2} \mathrm{O}_{3}$, the stable manganese oxide species at temperatures up to $970{ }^{\circ} \mathrm{C}$. In the second stage, the specimen releases oxygen, transforming into $\mathrm{Mn}_{3} \mathrm{O}_{4}$. Manganese carbonate is decomposed to $\mathrm{MnO}$ by heating under vacuum conditions or high temperatures (more than $1200^{\circ} \mathrm{C}$ ). Supplying oxygen to a sample of $\mathrm{MnO}$ formed by heating $\mathrm{MnCO}_{3}$ under vacuum results in $\mathrm{Mn}_{2} \mathrm{O}_{3}$ or $\mathrm{Mn}_{3} \mathrm{O}_{4}$, depending on the temperature, but not in $\mathrm{MnO}_{2}$, in this case, our sample present only 3 transformations, but the third mass loss is not attributed to manganese transformation [16]. Heating $\mathrm{MnCO}_{3}$ in air, however, yields $\alpha-\mathrm{MnO}_{2}$ in a poorly crystallized form (Figure 4). Although the most stable form of manganese oxide is $\mathrm{MnO}$, this species is formed at temperatures above $1200{ }^{\circ} \mathrm{C}$ in the heat treatment of $\mathrm{MnCO}_{3}$ in the presence of oxygen $[15-18,23]$.

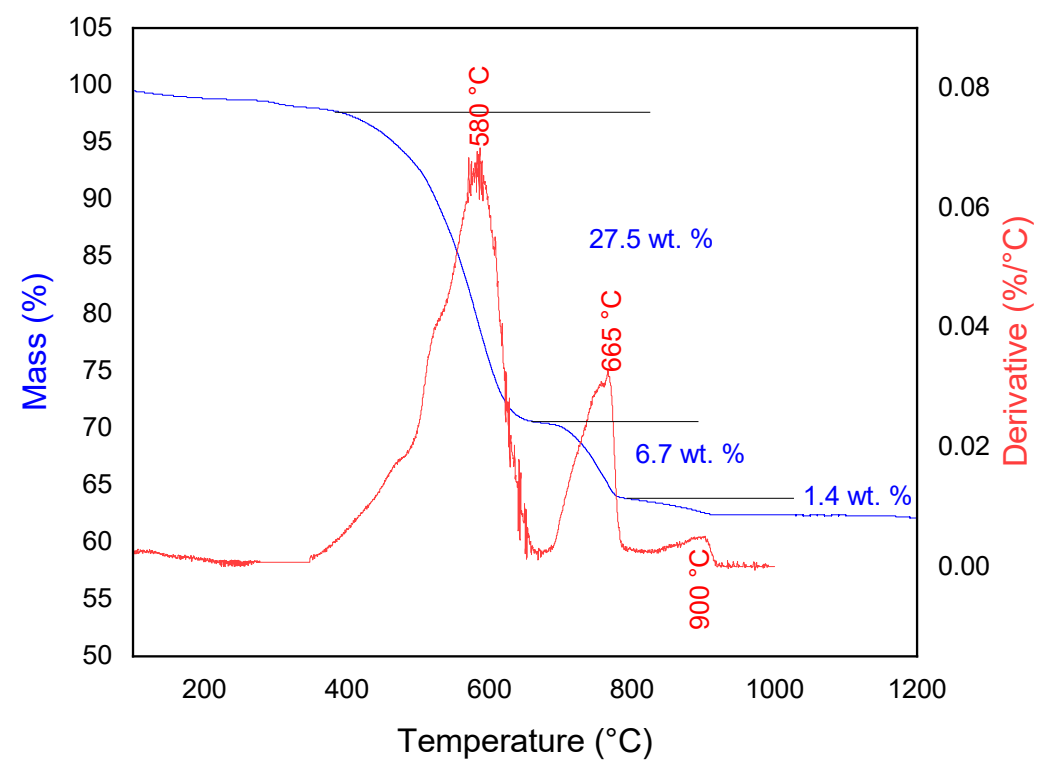

Figure 3. Thermogravimetric and derivative thermal analysis of rhodochrosite (TG-DTG).

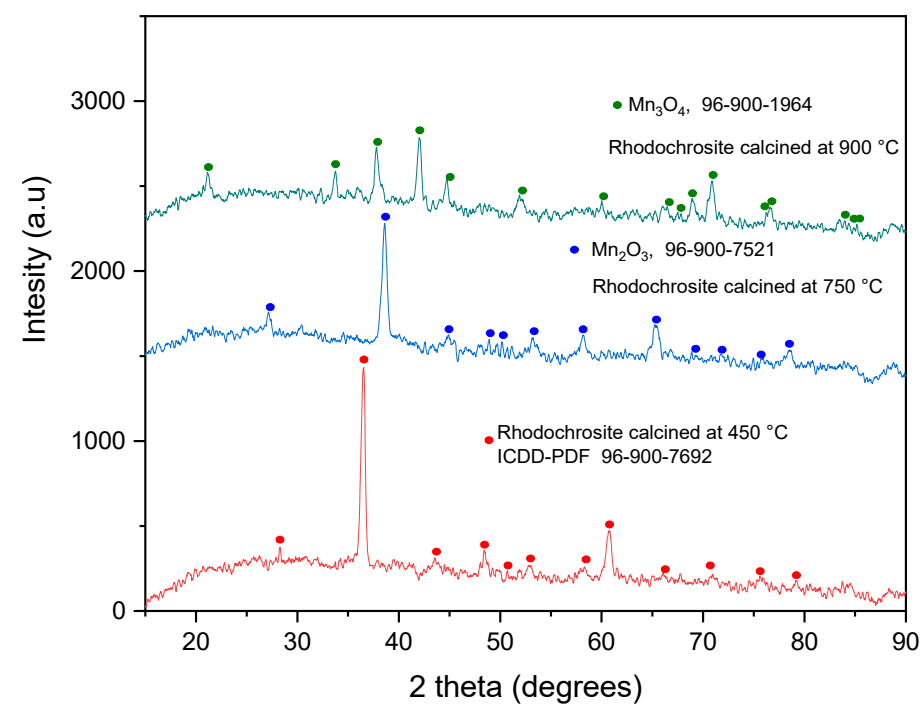

Figure 4. XRD diffractogram of calcined powders of rhodochrosite at different temperatures. 

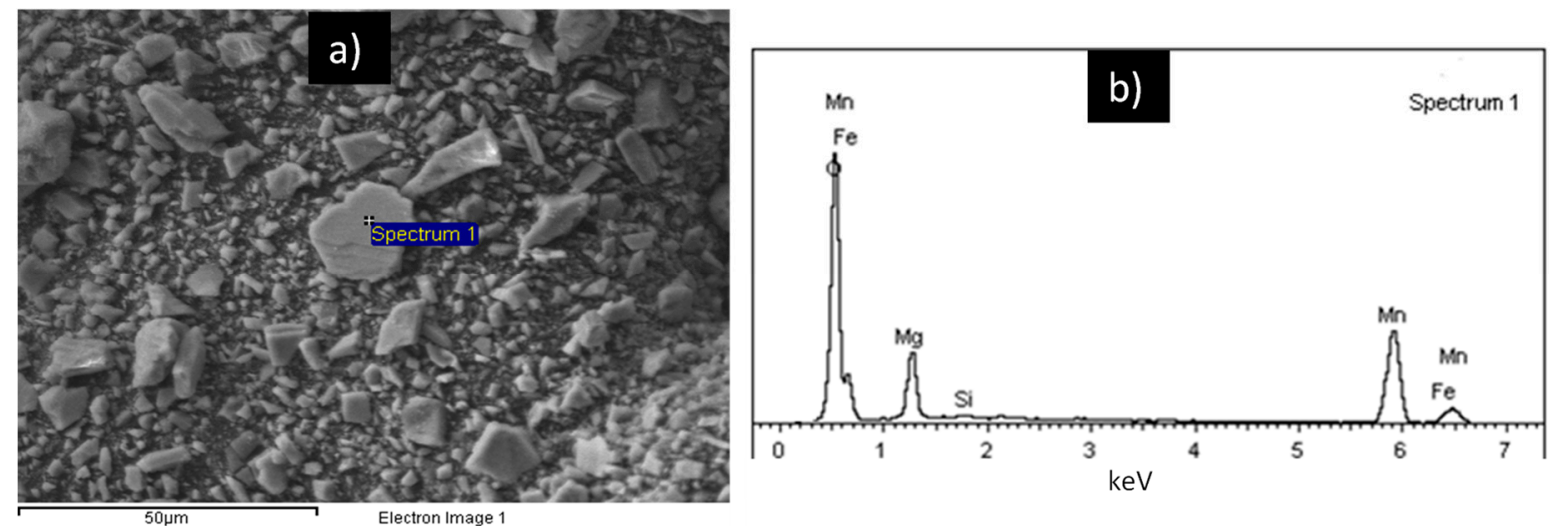

Figure 5. (a) FESEM image of rhodochrosite calcination residues $\left(900^{\circ} \mathrm{C}\right)$ and $(\mathbf{b})$ EDX analysis.

As shown in Figure 6, the FTIR analysis confirms that the $\mathrm{MnCO}_{3}$ is decomposed to $\alpha-\mathrm{Mn}_{2} \mathrm{O}_{3}$ and $\alpha-\mathrm{Mn}_{2} \mathrm{O}_{3}$ is transformed to $\mathrm{Mn}_{3} \mathrm{O}_{4}$. At $25{ }^{\circ} \mathrm{C}$, three intense bands appear at 1404,862 and $727 \mathrm{~cm}^{-1}$, corresponding to the asymmetric stretching $\left(v_{3}\right)$, in-plane $\left(v_{2}\right)$ and out-of-plane $\left(v_{4}\right)$ bending vibrations of the $\mathrm{CO}_{3}{ }^{2-}$ group respectively [25-30]; a very weak band appearing around $1080 \mathrm{~cm}^{-1}$ can be assigned to the $v_{1}$ symmetric stretching vibration $[25,29]$, while those appearing at higher wavenumbers $\left(2493\right.$ and $\left.1800 \mathrm{~cm}^{-1}\right)$ are probably due to overtones or combination bands, frequently found in carbonate minerals [25]. As the calcination temperature is increased, $\mathrm{MnCO}_{3}$ is first converted to $\alpha-\mathrm{Mn}_{2} \mathrm{O}_{3}$, as evidenced by both the emerging sharp $\left(603 \mathrm{~cm}^{-1}\right)$ and broad $\left(500 \mathrm{~cm}^{-1}\right)$ peaks $\left(450{ }^{\circ} \mathrm{C}\right)$ and the diminishing intensity of the bands 1404,862 and $727 \mathrm{~cm}^{-1}$ due to $\mathrm{CO}_{3}{ }^{2-}$ of the rhodochrosite. Further increases in the calcination temperature resulted in the complete decomposition of the carbonate material into a mixture of oxides $\left(\alpha-\mathrm{Mn}_{2} \mathrm{O}_{3}\right.$ and $\left.\mathrm{Mn}_{3} \mathrm{O}_{4}\right)$ at $750{ }^{\circ} \mathrm{C}$ and finally pure $\mathrm{Mn}_{3} \mathrm{O}_{4}$ phase at $950{ }^{\circ} \mathrm{C}$. As can be observed at $750{ }^{\circ} \mathrm{C}$ no evidence of any of the $\mathrm{CO}_{3}{ }^{2-}$ characteristic vibration bands were found. The sharp peak at $564 \mathrm{~cm}^{-1}$ is due to $\alpha-\mathrm{Mn}_{2} \mathrm{O}_{3}$ and the bands appearing at $655,475 \mathrm{~cm}^{-1}$ are attributed to $\mathrm{Mn}_{3} \mathrm{O}_{4}$ [30-32] The latter two bands, together with a weak, rounded band observed around $972 \mathrm{~cm}^{-1}$ and the strong, sharp peak appearing at $606 \mathrm{~cm}^{-1}$ at $900{ }^{\circ} \mathrm{C}$, are all assigned to $\mathrm{Mn}_{3} \mathrm{O}_{4}$ [30-33] stretching vibrations.

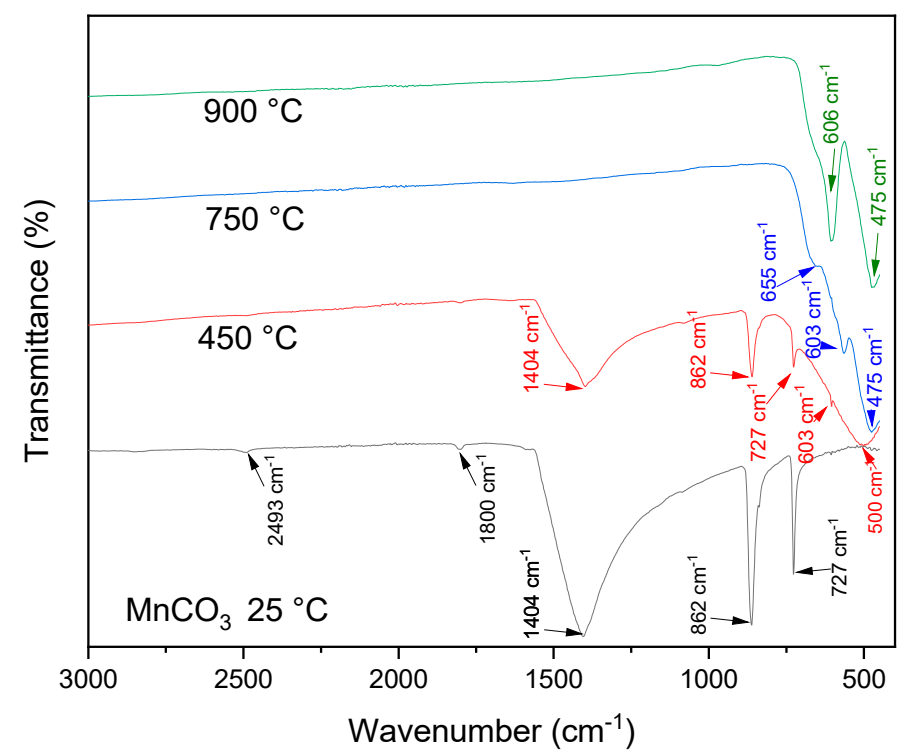

Figure 6. FTIR spectra of calcined powders of rhodochrosite at different temperatures. 
Table 2 shows the proposed reduction process taking place in the thermal treatment of rhodochrosite, specifying the initial and final temperatures for the reactions that occur. These reactions are similar to those proposed by different authors, coinciding in the different thermal decomposition products and in the temperature ranges in which they are carried out $[15,16,23]$.

Table 2. Proposed reactions occurring in the thermal decomposition of rhodochrosite.

\begin{tabular}{cccc}
\hline Stage & $\mathbf{T}_{\mathbf{0}}$ & $\mathbf{T}_{\mathbf{f}}$ & Reaction \\
\hline 1 & $350{ }^{\circ} \mathrm{C}$ & $660{ }^{\circ} \mathrm{C}$ & $2 \mathrm{Mn} \mathrm{CO}_{3}+\frac{1}{2} \mathrm{O}_{2} \rightarrow \mathrm{Mn}_{2} \mathrm{O}_{3}+2 \mathrm{CO}_{2}$ \\
2 & $660{ }^{\circ} \mathrm{C}$ & $780{ }^{\circ} \mathrm{C}$ & $3 \mathrm{Mn}_{2} \mathrm{O}_{3} \rightarrow 2 \mathrm{Mn}_{3} \mathrm{O}_{4}+\frac{1}{2} \mathrm{O}_{2}$ \\
3 & $780{ }^{\circ} \mathrm{C}$ & $900{ }^{\circ} \mathrm{C}$ & $\mathrm{Mn}_{3} \mathrm{O}_{4}$ \\
\hline
\end{tabular}

\subsection{Kinetics of Thermal Decomposition}

The kinetics of thermal decomposition was investigated considering the three mass losses experienced by the rhodochrosite. The method called "time to a given fraction" was used to determine the apparent activation energy for each of the stages [19-22].

By this method, it is possible to determine the apparent activation energy, $E a$, independent of the function $f(y)$ in the rate equation; it is also possible to determine if $E a$ varies during the course of a transformation. The method is based on the fact that the fraction-transformed " $y$ " and time " $t$ " are functionally related, therefore it is possible to consider $t$ as the dependent variable (see Equations (1)-(4))

$$
\begin{gathered}
\frac{d y}{d t}=k \cdot f(y) \\
d t=k^{-1} f^{-1}(y) d y
\end{gathered}
$$

The time ty to transform a given fraction $y=\mathrm{Y}$ is then

$$
t_{y}=k^{-1} \int_{y=0}^{y=Y} f^{-1}(y) d y
$$

where $t_{y}$ is the time at a given transformation stage, $k$ is the rate constant, $y$ is the material transformed fraction, and $f(y)$ is a function of $y$.

$$
\ln t_{y}=\text { const }-\ln A+\frac{E_{a}}{R}\left(\frac{1}{T}\right)
$$

where $A$ is the Arrhenius constant (frequency factor), $E a$ is the apparent activation energy, $R$ is the ideal gases constant $\left(8.3144 \mathrm{~J} \mathrm{~mol}^{-1} \mathrm{~K}^{-1}\right)$, and $T$ is the temperature in Kelvin $(K)$. The rate constant can be estimated by the Arrhenius law.

The time $t_{y}$ to the chosen value of the fraction transformed $Y$ is determined from a series of isothermal experiments carried out at several temperatures. The integrated equation, where $E a$ represents the apparent activation energy for the time required to reach certain reaction progress, is given by Equation (6). The slope of the plot of ln ty versus $1000 / \mathrm{T}$ is then used to calculate $E a$ (Equation (6)) [19-22], which represents the apparent activation energy for the time required to reach certain reaction progress.

The transformed fraction for the temperatures of each of the three stages was calculated using Equation (5), to determine the thermal decomposition kinetics and obtain the transformation at a given time $[19,34,35]$.

$$
y=\frac{\left(m_{0}-m_{t}\right)}{\left(m_{0}-m_{f}\right)}
$$


where $y$ is the mass fraction reacted, $m_{0}$ is the mass at the beginning of the experiment, $m_{t}$ is the mass at a given time $t$, and $m_{f}$ is the mass at the end of the experiment [36-38].

Figure 7 shows the profile of reacted fractions for each stage. The first mass loss (Figure 7a) has four temperatures, since it presents a long slope with a wide range of temperatures and isotherms of different temperatures can be obtained. These four temperatures show similar behavior. The next two mass losses (Figure $7 \mathrm{~b}, \mathrm{c}$ ) exhibit non-linear behavior. Here, only three temperatures were considered for each loss in the last two stages.
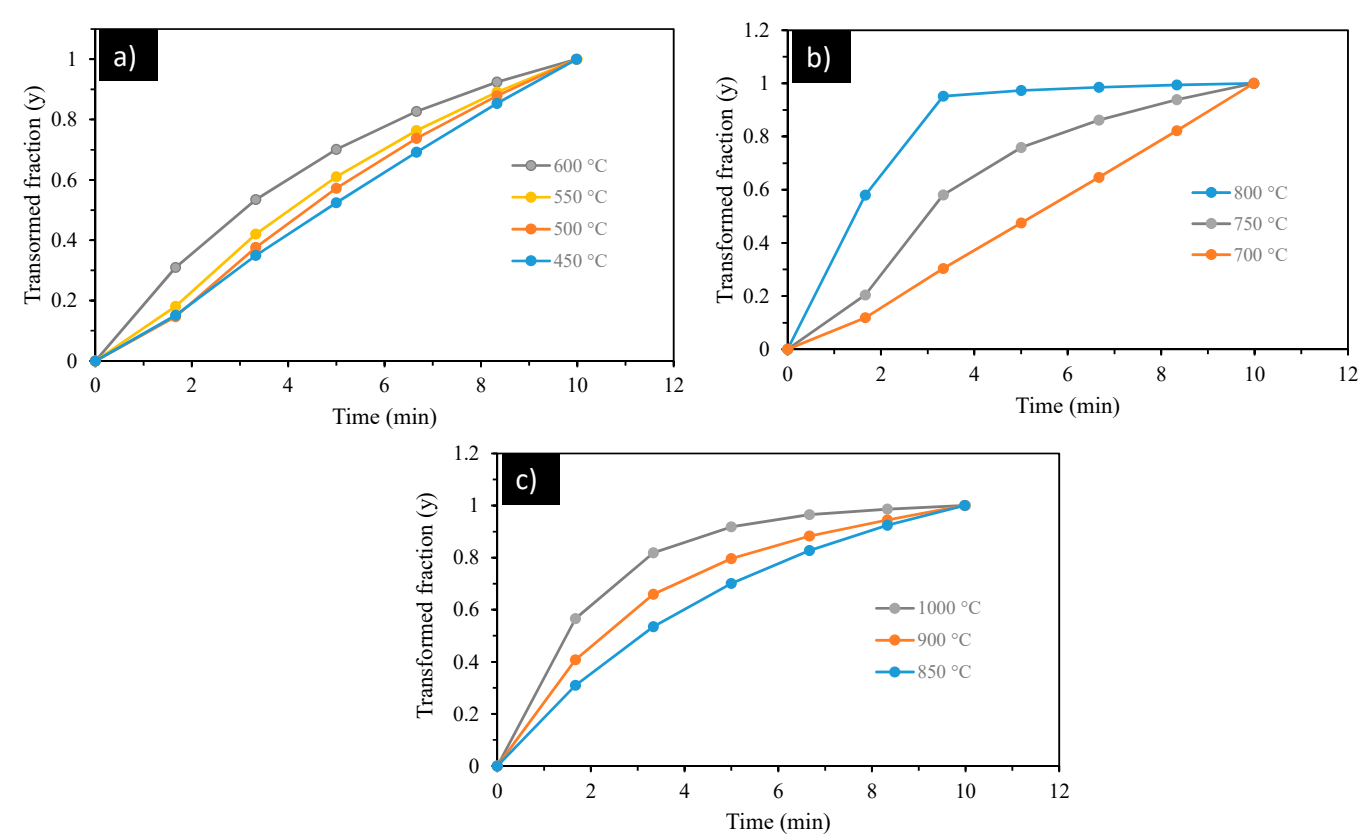

Figure 7. Transformed fraction of rhodochrosite thermal decomposition: (a) first mass loss, (b) second mass loss, and (c) third mass loss.

Table 3 summarizes the temperatures of each stage of thermal decomposition, the time taken to reach $50 \%$ transformation $\left(t_{y}, y=0.50\right)$, and the apparent activation energy values obtained from Figures 8-10. " $y$ " could have any transformation value, thus obtaining similar apparent activation energy values.

Table 3. Time taken to reach $50 \%$ of conversion $(y=0.5)$ from the data obtained in Figure 7.

\begin{tabular}{|c|c|c|c|c|c|}
\hline Stage & $\begin{array}{c}\text { Time to } 50 \%, \\
t_{Y}(\mathrm{~min})\end{array}$ & $\ln \left(t_{Y}\right)$ & Temperature $\left({ }^{\circ} \mathrm{C}\right)$ & $1000 / \mathrm{T}\left(\mathrm{K}^{-1}\right)$ & $\frac{E_{\mathrm{a}}}{\left(\mathrm{kJ} \cdot \mathrm{mol}^{-1}\right)}$ \\
\hline \multirow{4}{*}{ First } & 5.181 & 1.644 & 450 & 1.383 & \multirow{4}{*}{17.91} \\
\hline & 4.766 & 1.561 & 500 & 1.293 & \\
\hline & 4.029 & 1.393 & 550 & 1.215 & \\
\hline & 3.075 & 1.123 & 600 & 1.145 & \\
\hline \multirow{3}{*}{ Second } & 5.240 & 1.656 & 700 & 1.027 & \multirow{3}{*}{112.41} \\
\hline & 2.976 & 1.089 & 750 & 0.977 & \\
\hline & 1.430 & 0.357 & 800 & 0.931 & \\
\hline \multirow{3}{*}{ Third } & 2.275 & 0.819 & 850 & 0.890 & \multirow{3}{*}{64.69} \\
\hline & 1.470 & 0.385 & 900 & 0.852 & \\
\hline & 0.982 & -0.020 & 1000 & 0.785 & \\
\hline
\end{tabular}




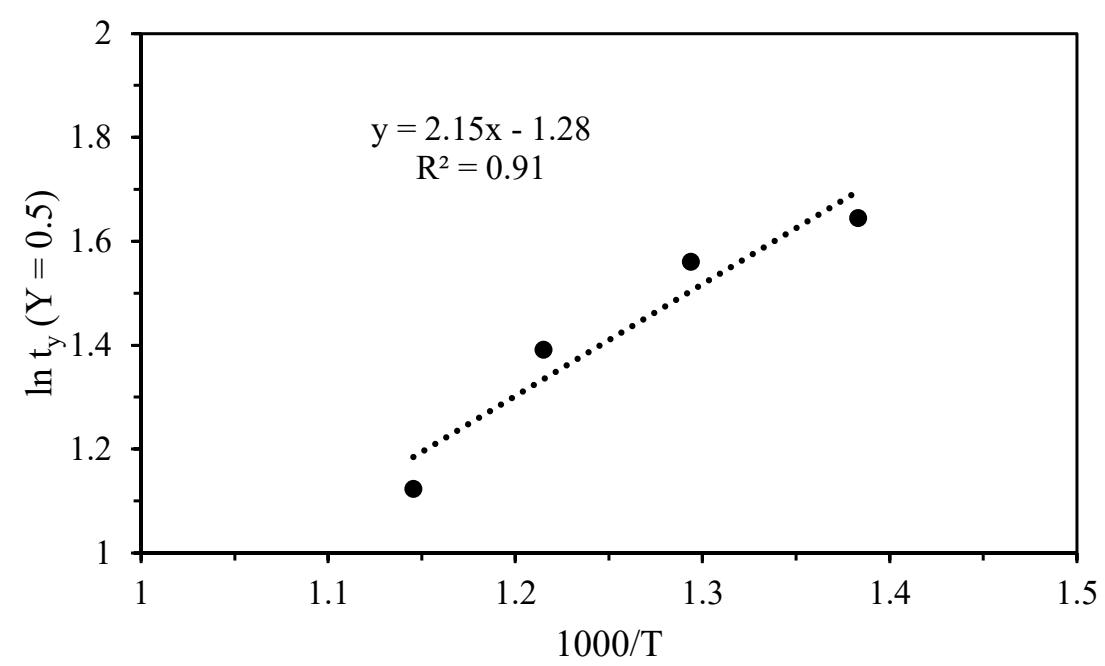

Figure 8. Determination of the apparent activation energy required for the conversion of $\mathrm{MnCO}_{3}$ to $\mathrm{Mn}_{2} \mathrm{O}_{3}$.

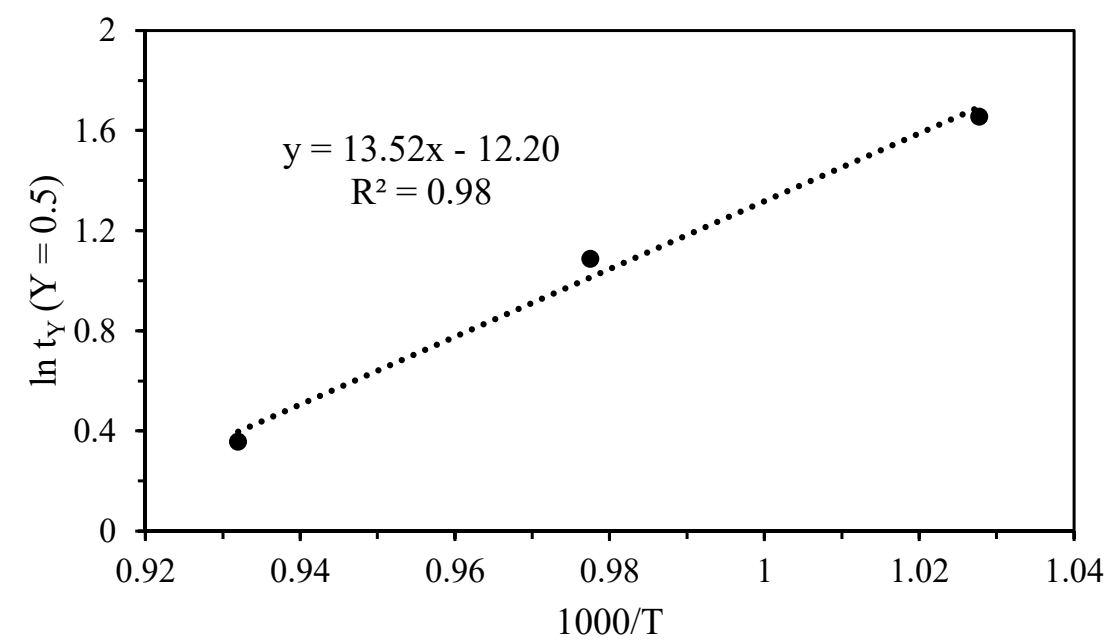

Figure 9. Determination of the apparent activation energy required for the conversion of $\mathrm{Mn}_{2} \mathrm{O}_{3}$ to $\mathrm{Mn}_{3} \mathrm{O}_{4}$.

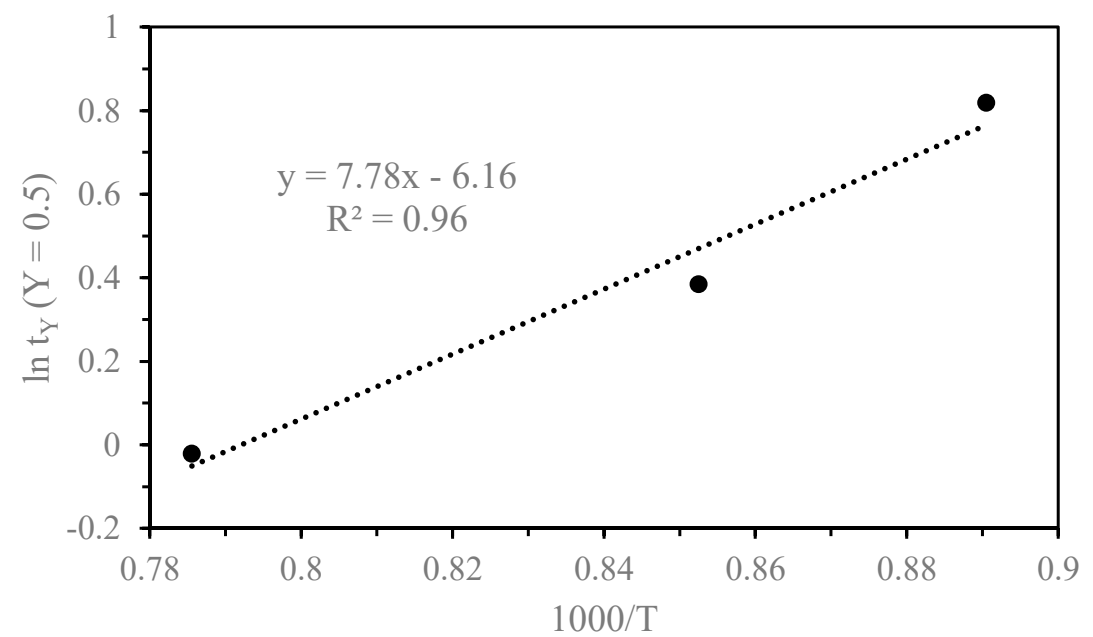

Figure 10. Determination of the energy required for the decomposition of $\mathrm{CaCO}_{3}$. 
From Figure 8, the apparent activation energy of the first mass loss $(27.5 \%)$ can be calculated. It results in an apparent activation energy of $17.91 \mathrm{~kJ} \mathrm{~mol}^{-1}$, with a frequency factor of 3.607; thus, it is a process controlled by mass transfer (diffusion-controlled process) $[20,22,34,35]$. This is because the thermal stability of the carbonates increases with the size of the cations that compose them; in this way, for a given period, the stability grows with the group of alkaline earth towards alkali. The manganese carbonate does not have high thermal stability, hence, a slow mass transfer is sufficient for the transformation to manganese (III) oxide $\left(\mathrm{Mn}_{2} \mathrm{O}_{3}\right)$, where manganese atoms are found at two different octahedral sites. Additionally, $\mathrm{Mn}_{2} \mathrm{O}_{3}$ has four short $\mathrm{Mn}-\mathrm{O}$ bonds and two longer ones.

This oxide $\left(\mathrm{Mn}_{2} \mathrm{O}_{3}\right)$ has a greater capacity of oxygen adsorption providing more stability than $\mathrm{MnCO}_{3}$, since it is a type-p semiconductor, which leads to an increase in the catalytic performance of this species with respect to type-n semiconductors or insulators.

The apparent activation energy for the second mass loss $(6.7 \%)$ was $112.41 \mathrm{~kJ} \mathrm{~mol}^{-1}$, with a frequency factor of 199,386 (Figure 9), indicating a rate-controlling process [20,22,34,35]; therefore, a greater amount of thermal energy is required to reduce manganese (III) oxide $\left(\mathrm{Mn}_{2} \mathrm{O}_{3}\right)$ and convert it to manganese tetroxide $\left(\mathrm{Mn}_{3} \mathrm{O}_{4}\right)$, also known as hausmannite. This oxide has a distorted spinel structure, $\left(\mathrm{Mn}^{+2}\left[\mathrm{Mn}_{2}^{+3}\right] \mathrm{O}_{4}\right)$, where $\mathrm{Mn}^{+2}$ cations occupy tetrahedral sites and $\mathrm{Mn}^{+3}$ cations occupy octahedral sites.

Finally, the apparent activation energy (Figure 10) corresponding to the third mass loss was found to be $64.69 \mathrm{~kJ} \mathrm{~mol}^{-1}$, with a frequency factor of 475,230 ; this indicates that the transformation is also conducted by a rate-controlling process $[20,22,34,35]$. The third mass loss is only $1.4 \%$, and it can be attributed to the decomposition of calcium carbonate $\left(\mathrm{CaCO}_{3}\right)$, which is present as an impurity in the mineral $[39,40]$.

\section{Conclusions}

An XRF analysis of the rhodochrosite sample obtained from the mining district of Molango, Hidalgo, Mexico, indicates the presence of $86.89 \%$ manganese carbonate $\left(\mathrm{MnCO}_{3}\right)$; this was verified with the XRD analysis. According to the thermogravimetric analysis, three mass losses of the mineral rhodochrosite were found. The first loss of $27.5 \%$ is attributed to the conversion of the carbonate to manganese (III) oxide with an activation energy of $17.91 \mathrm{~kJ} \mathrm{~mol}^{-1}$. The second loss is attributed to the conversion of manganese (III) oxide into manganese (II,III) tetroxide $\left(\mathrm{Mn}_{3} \mathrm{O}_{4}\right)$. In this oxide reduction, an apparent activation energy of $112.41 \mathrm{~kJ} \mathrm{~mol}^{-1}$, was calculated, indicating that the conversion depends entirely on the temperature. XRD and FTIR analysis were used to identify the residues after each of the mass losses, which confirming the observed material composition changes. Kinetic parameters show that not much energy is required to convert manganese carbonate into its different oxides; however, high temperatures are required to decontaminate rhodochrosite due to the thermal stability of the different carbonates contained in the mineral. With the kinetic parameters obtained (activation energy and the frequency factor), the fuel required to feed the nodulation furnaces can be calculated.

Author Contributions: Formal analysis, J.C.J.; Investigation, I.A.R., M.F. and C.A.P.; Methodology, H.I. and A.M.T.; Supervision, E.G.P. and M.R. All authors have read and agreed to the published version of the manuscript.

Funding: This research received no external funding

Institutional Review Board Statement: Not applicable.

Informed Consent Statement: Not applicable.

Data Availability Statement: All data presented is original.

Conflicts of Interest: The authors declare no conflict of interest.

\section{References}

1. Wolfram, O.; Krupp, R.E. Hydrothermal solubility of rhodochrosite, Mn (II) speciation, and equilibrium constants. Geochim. Cosmochim. Acta 1996, 60, 3983-3994. [CrossRef] 
2. Kim, S.T.; Kang, J.O.; Yun, S.T.; O’Neil, J.R.; Mucci, A. Experimental studies of oxygen isotope fractionation between rhodochrosite $\left(\mathrm{MnCO}_{3}\right)$ and water at low temperatures. Geochim. Cosmochim. Acta 2009, 73, 4400-4408. [CrossRef]

3. Casaletto, M.P.; Fierro, G. Surprising formation of a rhodochrosite-like $\left(\mathrm{MnCO}_{3}\right)$ phase on Co-Zn-Mn sintered spinels upon storage at room temperature and ambient air. Appl. Surf. Sci. 2017, 421, 97-108. [CrossRef]

4. Thackeray, M.M.; Johnson, C.S.; Vaughey, J.T.; Li, N.; Hackney, S.A. Advances in manganese-oxide composite electrodes for lithium-ion batteries. J. Mater. Chem. 2005, 15, 2257-2267. [CrossRef]

5. Yabuuchi, N.; Kajiyama, M.; Iwatate, J.; Nishikawa, H.; Hitomi, S.; Okuyama, R.; Usui, R.; Yamada, Y.; Komaba, S. P2-type $\mathrm{Na}_{(\mathrm{x})}\left[\mathrm{Fe}_{(1 / 2)} \mathrm{Mn}_{(1 / 2)}\right] \mathrm{O}_{2}$ made from earth-abundant elements for rechargeable Na batteries. Nat. Mater. 2012, 11, 512-517. [CrossRef] [PubMed]

6. Venkatesan, T.; Rajeswari, M.; Dong, Z.W.; Ogale, S.B.; Ramesh, R. Manganite-Based Devices: Opportunities, Bottlenecks and Challenges. Philos. Trans. R. Soc. Lond. Ser. A 1998, 356, 1661-1680. [CrossRef]

7. Edwin Suresh Raj, A.M.; Mallika, C.; Sreedharan, O.M.; Nagaraja, K.S. Manganese oxide-manganese tungstate composite humidity sensors. Mater. Lett. 2002, 53, 316-320. [CrossRef]

8. Cui, X.; Liu, G.; Lin, Y. Amperometric biosensors based on carbon paste electrodes modified with nanostructured mixed-valence manganese oxides and glucose oxidase. Nanomed. Nanotechnol. 2005, 1, 130-135. [CrossRef] [PubMed]

9. Kim, K.J.; Park, Y.R. Sol-gel growth and structural and optical investigation of manganese-oxide thin films: Structural transformation by Zn doping. J. Cryst. Growth 2004, 270, 162-167. [CrossRef]

10. Nakamura, H.; Kohn, K. Magnetoelectric effect of rare earth manganese oxide $\mathrm{RMn}_{2} \mathrm{O}_{5}$. Ferroelectrics 1997, $204,107-114$. [CrossRef]

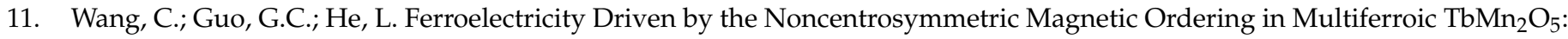
A First-Principles Study. Phys. Rev. Lett. 2007, 99, 1-4. [CrossRef] [PubMed]

12. Pereira, M.J.; Lima, M.M.F.; Lima, R.M.F. Calcination and characterization studies of a Brazilian manganese ore tailing. Int. J. Miner. Process. 2014, 131, 26-30. [CrossRef]

13. Gao, Y.; Olivas-Martinez, M.; Sohn, H.Y.; Kim, H.G.; Kim, C.W. Upgrading of low grade manganese ore by selective reduction of iron oxide and magnetic separation. Metall. Mater. Trans. B 2012, 43, 1465-1475. [CrossRef]

14. Loofbourow, R.L. Mining Methods and Costs at Granada Gold Mines, Ltd. Rouyn, Quebec; University of Michigan Library: Quebec, QC, Canada, 1933.

15. Available online: https://www.autlan.com.mx/en/business-units/autlan-manganese/molango-unit/ (accessed on 31 August 2020).

16. Kissinger, H.G.; McMurdie, H.F.; Simpson, B.S. Thermal Decomposition of Manganous and Ferrous Carbonates. J. Am. Ceram. Soc. 1955, 24, 168-172. [CrossRef]

17. Biernacki, L.; Pokrzywnicki, S. The thermal decomposition of manganese carbonate. J. Therm. Anal. Calorim. 1999, 55, 227-232. [CrossRef]

18. Fazeli, A.R.; Taren, J.; Basavalingu, B.; Bhandage, G.T. Standard thermodynamic data for Rhodochrosite from equilibrium decomposition curve. Proc. Indian Acad. Sci. (Earth Planet. Sci.) 1991, 100, 37-40.

19. Putnis, A. Introduction to Mineral Sciences; Cambridge University Press: Cambridge, UK, 1992.

20. Hidalgo, T.; Kuhar, L.; Beinlich, A.; Putnis, A. Kinetics and mineralogical analysis of copper dissolution from a bornite/chalcopyrite composite sample in ferric-chloride and methanesulfonic-acid solutions. Hydrometallurgy 2019, 188, 140-156. [CrossRef]

21. Jiménez, A.; Prieto, M. Thermal Stability of Ettringite Exposed to Atmosphere: Implications for the Uptake of Harmful Ions by Cement. Environ. Sci. Technol. 2015, 49, 7957-7964. [CrossRef]

22. Redfern, S.A.T. The kinetics of dehydroxylation of kaolinite. Clay Miner. 1987, 22, 447-456. [CrossRef]

23. Available online: https://www.netzsch-thermal-analysis.com/en/materials-applications/batteries/manganese-oxidereduction/ (accessed on 28 August 2020).

24. Zhao, Y.; Zhu, G.; Cheng, Z. Thermal analysis and kinetic modeling of manganese oxide ore reduction using biomass straw as reductant. Hydrometallurgy 2010, 105, 96-102. [CrossRef]

25. Ray, L.F.; Jiří, C.; Godwin, A.A.; Marilla, J.D. Raman spectroscopic study of the uranyl carbonate mineral voglite. J. Raman. Spectrosc. 2008, 39, 374-379.

26. Zhang, R.H.; Zhao, D.; Huang, M.; Yang, R.J.; Ma, F.X.; Fan, Y.C. Synthesis, crystal structure and photoluminescence properties of a new rare-earth carbonate $\mathrm{Na}_{3} \mathrm{Eu}\left(\mathrm{CO}_{3}\right)_{3} \cdot 6 \mathrm{H}_{2} \mathrm{O}$. J. Chil. Chem. Soc. 2017, 62, 3403-3406. [CrossRef]

27. Grunenwald, A.; Keyser, C.; Sautereau, A.M.; Crubézy, E.; Ludes, B.; Drouet, C. Revisiting carbonate quantification in apatite (bio) minerals: A validated FTIR methodology. J. Archaeol. Sci. 2014, 49, 134-141. [CrossRef]

28. Hu, H.; Xu, J.Y.; Yang, H.; Liang, J.; Yang, S.; Wu, H. Morphology-controlled hydrothermal synthesis of $\mathrm{MnCO}_{3}$ hierarchical superstructures with Schiff base as stabilizer. Mater. Res. Bull. 2011, 46, 1908-1915. [CrossRef]

29. Menezes, P.A.; Indra, A.; Bergmann, A.; Chernev, P.; Walter, C.; Dau, H.; Strasser, P.; Driess, M. Uncovering the prominent role of metal ions in octahedral versus tetrahedral sites of cobalt-zinc oxide catalysts for efficient oxidation of water. J. Mater. Chem. 2016, 1, 1-25. [CrossRef]

30. Ashoka, S.; Chithaiah, P.; Tharamani, C.N.; Chandrappa, G.T. Synthesis and characterisation of microstructural $\alpha-\mathrm{Mn}_{2} \mathrm{O}_{3}$ materials. J. Exp. Nanosci. 2010, 5, 285-293. [CrossRef] 
31. Finocchio, E.; Busca, G. Characterization and hydrocarbon oxidation activity of coprecipitated mixed oxides $\mathrm{Mn}_{3} \mathrm{O}_{4} / \mathrm{Al}_{2} \mathrm{O}_{3}$. Catal. Today 2001, 70, 213-225. [CrossRef]

32. Julien, C.M.; Massot, M.; Poinsignon, C. Lattice vibrations of manganese oxides: Part I. Periodic structures. Spect. Acta A 2004, 60, 689-700. [CrossRef]

33. Lakshmi, S.V.; Pauline, S.; Vinosel, V.M. Microstructural Characteriztion of Trimanganese Tetra Oxide (Mn3O4) Nanoparticle by Solvothermal Method and Its Dielectric Studies. Int. J. Eng. Sci. Technol. 2014, 3, 123-131.

34. Ballester, A.; Verdeja, L.F.; Sancho, J. Metalurgia Extractiva, 2nd ed.; Síntesis: Barcelona, Spain, 2000; Volume I.

35. Levenspiel, O. Ingeniería de las Reacciones Químicas, 2nd ed.; Reverté: Barcelona, Spain, 2002.

36. Flores, M.U.; Reyes, I.A.; Palacios, E.G.; Patiño, F.; Juárez, J.C.; Reyes, M.; Teja, A.M.; Islas, H.; Gutiérrez, E.J. Kinetic analysis of the thermal decomposition of a synthetic mercury jarosite. Minerals 2019, 9, 200. [CrossRef]

37. Torrente, M.C.; Galán, M.A. Kinetics of the thermal decomposition of oil shale from Puertollano (Spain). Fuel 2001, 80, 327-334. [CrossRef]

38. Khachani, M.; Hamidi, A.E.; Kacimi, M.; Halim, M.; Arsalane, S. Kinetic approach of multi-step thermal decomposition processes of iron (III) phosphate dihydrate $\mathrm{FePO}_{4} \cdot 2 \mathrm{H}_{2} \mathrm{O}$. Thermochim. Acta 2015, 610, 29-36. [CrossRef]

39. Ingraham, T.R.; Marier, P. Kinetic studies on the thermal decomposition of calcium carbonate. Can. J. Chem. Eng. 1963, 41, 170-173. [CrossRef]

40. Kohobhange, S.P.K.; Manoratnea, C.H.; Pitawalab, H.M.T.G.A.; Rajapaksec, R.M.G. Thermal decomposition of calcium carbonate (calcite polymorph) as examined by in-situ high-temperature X-ray powder diffraction. J. Phys. Chem. Solids 2019, 134, 21-28. 